\title{
WASTEWATER USE IN AGRICULTURE: ANALYTICAL LIMITS OF SEWAGE FOR IMPACT CONTROL IN BRAZIL ${ }^{1}$
}

\author{
DOUGLISNILSON DE MORAIS FERREIRA ${ }^{2 *}$, JULIO ALEJANDRO NAVONI $^{3}$, ANDRÉ LUIS CALADO ARAÚJO $^{3}$, \\ JULIANA DELGADO TINOCO ${ }^{4}$, VIVIANE SOUZA DO AMARAL ${ }^{2}$
}

\begin{abstract}
Water deficit is a current problem of global relevance. This is a problem in Brazil, especially in the Semiarid region, which undergoes severe droughts for much of the year. This requires the search for alternatives, such as the planned wastewater use, which is a successful alternative in developed countries that is applied for various purposes, including agriculture. However, despite the increasing growth of agriculture in Brazil, there are no established control and monitoring policies to minimize its impacts on the environment and human health. The country does not have specific legislation that defines wastewater quality parameters for domestic sewage. The objective of this work was to compile international guidelines and legislations that address this issue and compare them with the national normative resolutions for quality of wastewater and its different uses. The most relevant and locally applicable parameters described in these documents were listed, and the reference limits were defined by comparing them with those found in the scientific literature applied to the Brazilian context. This compilation represents the first step towards the incorporation of regulations for water reuse, having the Brazilian Semiarid region as a first test field, but with expandable application to different regions of the country.
\end{abstract}

Keywords: Agriculture. Legislation. Stabilization ponds.

\section{REÚSO AGRÍCOLA DE ÁGUAS NO BRASIL: LIMITES ANALÍTICOS DO EFLUENTE PARA CONTROLE DE IMPACTOS}

\begin{abstract}
RESUMO - O déficit hídrico é uma problemática atual de relevância mundial. No Brasil, em especial no semiárido, essa realidade alcança níveis elevados de seca em boa parte do ano, sendo necessária a busca de alternativas mitigadoras, como o reúso planejado de águas residuárias, alternativa instaurada com sucesso nos países desenvolvidos, aplicado para diversos fins, inclusive na agricultura. No cenário nacional, mesmo diante do acentuado crescimento dessa atividade, não existem, políticas definidas de controle e monitoramento que visam minimizar impactos causados ao meio ambiente e à saúde humana. Ademais, o país não dispõe de legislação específica que contemple parâmetros da qualidade de água de reúso proveniente de esgoto doméstico. Nesse sentido, este trabalho teve como objetivo analisar as diretrizes e legislações internacionais que tratam dessa temática associadas às normativas nacionais que discorrem sobre a qualidade da água de reúso em suas diversas aplicações. Foram elencados os parâmetros de maior relevância e aplicabilidade local, descritos nesses documentos, e os limites de referência definidos a partir da comparação com a bibliografia científica aplicada ao contexto brasileiro. Essa compilação representa o primeiro passo para uma futura incorporação regulamentar da atividade de reúso de águas, tendo como campo primário de aplicação o semiárido, mas expansível às diversas regiões do país.
\end{abstract}

Palavras-chave: Agricultura. Legislação. Lagoa de estabilização.

\footnotetext{
*Corresponding author

${ }^{1}$ Received for publication in 04/26/2019; accepted in 09/04/2019.

Paper extracted from the doctoral thesis of the first author.

${ }^{2}$ Postgraduate program in development and environment, Universidade Federal do Rio Grande do Norte, Natal, RN, Brazil; moraisdouglisnilson@gmail.com - ORCID: 0000-0003-0113-7730, vi.mariga@gmail.com - ORCID: 0000-0002-9326-9054.

${ }^{3}$ Academic Board of Natural Resources, Instituto Federal de Educação, Ciência e Tecnologia do RN, Natal, RN, Brazil; navoni.julio@gmail.com - ORCID: 0000-0001-8715-0527, andre.calado@ifrn.edu.br - ORCID: 0000-0001-5050-992X.

${ }^{4}$ Postgraduate program in sanitary and environmental engineering, Universidade Federal do Rio Grande do Norte, Natal, RN, Brazil; julianatinoco@ct.ufrn.br - ORCID: 0000-0001-9517-2320.
} 


\section{INTRODUCTION}

Uncontrolled water use had occurred for decades due to the belief that water is an inexhaustible resource. However, the combination of population growth, climate disasters, agricultural expansion, industrial development, exploitation of natural resources, and environmental degradation debunked this belief, and the world today is experiencing water scarcity (JACOBI; EMPINOTTI; SCHIMIDT, 2016). A projection shows that over 9.5 billion people will inhabit the planet by 2050 , agriculture will growth in approximately $60 \%$ and the water consumption in approximately $20 \%$; thus, if no significant changes in water management, use, and sharing occur, the global water security will be compromised, affecting human, economic, and social developments (EPA, 2012; VERIATO et al, 2015; CANTELLE; LIMA; BORGES, 2018).

Despite the large volume of available fresh water in Brazil, the country constantly undergoes water crises due to geographical and climatic factors, such as latitude, altitude, and continentality; and anthropogenic action, such as poor distribution, losses in the distribution networks, waste in domestic activities, pollution of water bodies by domestic and industrial sewage discharges, and the agricultural use which accounts for over $60 \%$ of all water demand. According to the Report on the Conjuncture of Water Resources in Brazil (ANA, 2017a), between 2003 and 2016, approximately 50\% $(2,783)$ of Brazilian municipalities declared state of emergency or calamity due to droughts. The Brazilian Northeast region is the area most prone to long periods of drought and has the most severe water problems, with $78.5 \%(1,409)$ of its municipalities affected in the same period (CIRILO, 2015; BEZERRA; BEZERRA, 2016).

Therefore, water reuse (use of water previously used for other human needs) is a tool for sustainability of water resources that is applied mainly for non-potable purposes, such as industrial, recreational, urban, and agricultural uses, promoting water savings, social-economic development, and reduction of environmental impacts (UCKER et al., 2013; HESPANHOL, 2015a; TUNDISI; TUNDISI, 2015). Countries, such as the United States and Israel, have been usng this alternative for decades, with reuse of 8 and 1 million $\mathrm{m}^{3}$ day $^{-1}$, respectively ( $80 \%$ in agriculture). This practice is also found in Europe, with approximately 700 projects for water reuse in agriculture, especially in Spain, France, and Portugal (SCHAER-BARBOSA; SANTOS; MEDEIROS, 2014; KUBLER; FORTIN; MOLLETA, 2015).

Water reuse in agriculture in Brazil started in the 1980s, with slow but gradual growth over the years. Currently, it is more intense in the northeastern states, mainly involving family farming and animal feed. However, the lack of regulations and monitoring of wastewater quality and its use results in exposure of plants to organic compounds, heavy metals, pathogens, and emerging pollutants (drugs, cosmetics, endocrine disruptors and their metabolites, and nanoparticles) that are harmful to human health and to the environment (HESPANHOL, 2015b; ROLIM et al., 2016).

In this context, the objective of this work was to compile international in force laws and regulations that establish permissible limits for the main parameters of sanitary interest physical, chemical, and microbiological in domestic sewage effluents used for agricultural purposes.

\section{MATERIALS AND METHODS}

The methodology used for this review consisted of bibliographic research of international laws and guidelines related to water reuse in agriculture, and comparisons of them with national articles. The articles were searched and cataloged based on combinations of keywords (three), with the term "reuse" present in all combinations, encompassing the largest possible number of studies focused on the issue.

The articles were searched in journals in the databases of the Institute for Scientific Information, Scielo, and Scopus, due to their vast contents and continuous updating, which include articles from national and international scientific publishers. The selection of the articles consisted of evaluations of their titles and abstracts, with preference for those published in the last 10 years. The articles of greatest relevance were cataloged for use. Regarding legislation and guidelines, the updated versions available for public consultation were used.

These documents were studied and issues of environmental interest were listed for the investigation of the quality of sewage applied for water reuse, which was grouped into four classes: organic matter, nutrient, and $\mathrm{pH}$; salt; pathogens; and metal. The maximum and minimum limits for each parameter was determined using the following criteria: I) they are values defined by international laws; II) they have compatibility with the concentrations in effluents predicted in literature for different treatment technologies; III) they are limits applied to agricultural irrigation considering impacts caused to crops; IV) they are from comparative studies with scientific researches in Brazil; V) they are from analysis compatible with the sewage discharge conditions in Brazil.

\section{RESULTS AND DISCUSSION}

Domestic sewage contains a high concentrations of nutrients, organic matter, and water 
(over 99\%); thus, its use has applications on agricultural activities, generating environmental, economic, and social benefits preservation of springs and reduction of water volume extracted from natural sources for agricultural activities; reduction of costs with commercial fertilizers; and improvement of life quality (EPA, 2012; MENDONÇA, 2017; LUCENA et al., 2018).

Considering the increasing growth of agriculture, the adoption of precise legislation has become essential for the safety of agricultural activities. The state of California (USA) has pioneered regulations for use of sewages (1918), which are still in use today, with updates due to changes in environmental quality caused by human activities. In 1973, the World Health Organization (WHO) published the Guidelines for the Safe Use of Wastewater, Excreta and Greywater, which was applied to agriculture, emphasizing treatment criteria and maximum pathogen concentrations (thermotolerant coliforms and helminths) (WHO, 2006). Another document of worldwide relevance is the Guidelines for Water Reuse, released in 1980 by the Environmental Protection Agency (EPA), which provides criteria for treatment and contaminant limits for water reuse in the United States. Table 1 summarizes these and other specific legislations.

Table 1. Comparison of legislations for water reuse in agriculture around the world, considering maximum limits for unrestricted use.

\begin{tabular}{|c|c|c|}
\hline Country / Legislation & Parameters & \\
\hline Mexico (1987) & $\mathrm{BOD}=30 \mathrm{mg} \mathrm{L}^{-1}$ & $\mathrm{TC}=1000 \mathrm{MPN}$ or CFU per $100 \mathrm{~mL}$ \\
\hline Israel (1999) & $\begin{array}{l}\mathrm{BOD}=20 \mathrm{mg} \mathrm{L}^{-1} \\
\text { Suspended solids }=10 \mathrm{mg} \mathrm{L}^{-1}\end{array}$ & $\mathrm{TC}=10 \mathrm{MPN}$ or CFU per $100 \mathrm{~mL}$ \\
\hline Australia (2000) & $\mathrm{pH}=6.5-8.5$ & $\mathrm{TC}=10^{2}-10^{4} \mathrm{MPN}$ or CFU per $100 \mathrm{~mL}$ \\
\hline Jordan (2002) & $\begin{array}{l}\text { BOD }=200-300 \mathrm{mg} \mathrm{L}^{-1} \\
\text { Suspended solids }=150 \mathrm{mg} \mathrm{L}^{-1} \\
\mathrm{pH}=6-9 \\
\text { Total phosphorus }=30 \mathrm{mg} \mathrm{L}^{-1}\end{array}$ & $\begin{array}{l}\text { Total nitrogen }=70 \mathrm{mg} \mathrm{L}^{-1} \\
\mathrm{TC}=1000 \mathrm{MPN} \text { or CFU per } 100 \mathrm{~mL} \\
\text { Helminths }=<1 \text { viable eggs } \mathrm{L}^{-1} \\
\mathrm{SAR}=9.0\end{array}$ \\
\hline $\begin{array}{l}\text { Italy } \\
\text { Dec. Minist. 15/2003 }\end{array}$ & $\begin{array}{l}\mathrm{BOD}=20 \mathrm{mg} \mathrm{L}^{-1} \\
\text { Total phosphorus }=2 \mathrm{mg} \mathrm{L}^{-1} \\
\text { Total nitrogen }=15 \mathrm{mg} \mathrm{L}^{-1} \\
\mathrm{pH}=6.0-9.5\end{array}$ & $\begin{array}{l}\mathrm{EC}=3000 \mu \mathrm{S} \mathrm{cm}^{-1} \\
\mathrm{TC}=100 \mathrm{MPN} \text { or CFU per } 100 \mathrm{~mL} \\
\mathrm{SAR}=10.0\end{array}$ \\
\hline Portugal (2006) & $\begin{array}{l}\text { Suspended solids }=60 \mathrm{mg} \mathrm{L}^{-1} \\
\mathrm{pH}=6.5-8.5 \\
\mathrm{EC}=1000 \mu \mathrm{S} \mathrm{cm}^{-1}\end{array}$ & $\begin{array}{l}\mathrm{TC}=10^{2}-10^{4} \mathrm{MPN} \text { or } \mathrm{CFU} \text { per } 100 \mathrm{~mL} \\
\mathrm{SAR}=8.0\end{array}$ \\
\hline China (2007) & $\begin{array}{l}\text { BOD }=60-100 \mathrm{mg} \mathrm{L}^{-1} \\
\text { Suspended solids }=80-100 \mathrm{mg} \mathrm{L}^{-1}\end{array}$ & $\begin{array}{l}\mathrm{pH}=5.5-8.5 \\
\mathrm{TC}=10^{4} \mathrm{MPN} \text { or } \mathrm{CFU} \text { per } 100 \mathrm{~mL}\end{array}$ \\
\hline $\begin{array}{l}\text { France }(2010) \\
\text { NOR-SASP1013629A }\end{array}$ & \multicolumn{2}{|c|}{$\mathrm{TC}=10^{4}-10^{5} \mathrm{MPN}$ or $\mathrm{CFU}$ per $100 \mathrm{~mL}$} \\
\hline $\begin{array}{l}\text { United States } \\
\text { EPA (2012) }\end{array}$ & $\begin{array}{l}\text { BOD }=10 \mathrm{mg} \mathrm{L}^{-1} \\
\mathrm{pH}=6.5-8.4 \\
\mathrm{TC}=200 \mathrm{MPN} \text { or CFU per } 100 \mathrm{~mL} \\
\text { Aluminum }=5.0 \mathrm{mg} \mathrm{L}^{-1} \\
\text { Arsenic }=0.10 \mathrm{mg} \mathrm{L}^{-1} \\
\text { Cadmium }=0.01 \mathrm{mg} \mathrm{L}^{-1} \\
\text { Lead }=5.0 \mathrm{mg} \mathrm{L}^{-1}\end{array}$ & $\begin{array}{l}\text { Coper }=0.2 \mathrm{mg} \mathrm{L}^{-1} \\
\text { Iron }=5.0 \mathrm{mg} \mathrm{L}^{-1} \\
\text { Nickel }=0.2 \mathrm{mg} \mathrm{L}^{-1} \\
\text { Selenium }=0.02 \mathrm{mg} \mathrm{L}^{-1} \\
\text { Zinc }=2.0 \mathrm{mg} \mathrm{L}^{-1} \\
\text { SAR }=9.0\end{array}$ \\
\hline Global WHO (2006) & Helminths $=\leq 1$ viable eggs $\mathrm{L}^{-1}$ & $\mathrm{TC}=10^{3}-10^{5} \mathrm{MPN}$ per $100 \mathrm{~mL}$ \\
\hline
\end{tabular}

WHO (2006); EPA (2012); Becerra-Castro et al. (2015). EC = Electrical Conductivity; BOD = Biochemical Oxygen Demand; $\mathrm{TC}=$ Thermotolerant Coliforms; SAR $=$ Sodium Adsorption Ratio; MPN $=$ most probable number; $\mathrm{CFU}=$ colony-forming unit.

Stabilization ponds in Brazil are the most comprehensive systems for domestic sewage treatment, mainly in the northeastern semiarid region, because they have a low-cost implementation process and easy operation (ARAÚJO et al., 2016). The variants of these systems are the anaerobic, aeration, facultative, and maturation ponds (LUCENA et al., 2018). According to the Sewer Atlas (ANA, 2017a), the most commonly found processes in Brazil are the anaerobic pond followed by the facultative pond (Australian system), representing 364 systems. The other processes represent 203 (facultative ponds) and 119 (facultative pond + maturation pond) systems. In the state of Rio Grande do Norte, $49 \%$ of the 78 existing systems have facultative pond configuration followed by two maturation (ARAÚJO, 2017).

Biochemical oxygen demand (BOD) is an 
indicator that indirectly determines the amount of oxygen required by aerobic microorganisms to stabilize biodegradable organic matter from domestic or industrial wastes and polluted water bodies, and is critical in pollution control and self-purification processes of water bodies (ANA, 2017b; MELO JÚNIOR et al., 2018). According to Von Sperling (2002), facultative ponds present greater efficiency in remove BOD $(75 \%$ to $85 \%)$ when used in systems with good efficiency and composed of serial ponds, reaching final concentrations of $60 \mathrm{mg} \mathrm{L}^{-1}$. These values are compatible with those established in laws of China and Portugal. However, the monitoring of sewage treatment systems (facultative followed by two maturation) showed average efficiency of $69 \%$ (ARAÚJO, 2017).

Phosphorus and Nitrogen are the main nutrients in domestic sewage, which are essential for the growth of microorganisms that are responsible for the stabilization of organic matter (VON SPERLING, 2002). High concentrations of $P$ and $N$ promote excessive algae growth (eutrophication of the water body) and cause toxicity to fish (ammonia) (MENDONÇA; MENDONÇA, 2017). Facultative stabilization ponds have removal rates of $35 \%$ (phosphorus) and 60\% (nitrogen), with final concentrations predicted in the domestic effluent of 4 to $10 \mathrm{mg} \mathrm{L}^{-1}(\mathrm{P})$ and 20 to $50 \mathrm{mg} \mathrm{L}^{-1}(\mathrm{~N})$ (VON SPERLING, 2002). According to the studied legislations, the limits for Jordan $70 \mathrm{mg} \mathrm{L}^{-1}(\mathrm{~N})$ and $30 \mathrm{mg} \mathrm{L}^{-1}$ (P) are compatible with the situation described by Araújo (2017) for the semiarid region of the state of Rio Grande do Norte, Brazil contents above $50 \mathrm{mg} \mathrm{L}^{-1}$ in some seasons.

Regarding the pathogens, the limits described by the WHO (2006) are similar to those expected for treatments in maturation ponds, which intend to eliminate mainly organisms that cause serious health problems, with removal estimate over $99.99 \%$ in well-operated systems composed of series of ponds (MENDONÇA, 2017). The results found in the predominant sewage treatment systems in the state of Rio Grande do Norte showed efficiencies of $97.92 \%$ to $99.99 \%$ (ARAÚJO, 2017).

The US legislation is a world reference in proposing safety limits for bioaccumulative chemicals, such as metals, which is also adopted by countries with advanced treatment systems, such as France, Italy, and Mexico; it guarantees high efficiency for control and elimination of these chemicals, and does not compromise the quality of the irrigated plants (EPA, 2012). The treatment systems adopted in Brazil do not intended to eliminate these chemicals, regardless of their concentrations found in domestic sewage. In addition, the lack of inspection of the effluents that reach the sewage treatment systems and the lack of sewage quality monitoring are factors that reinforce the need for the adoption of safety limits.

Some of these compounds have high toxicological potential and may bioaccumulate and biomagnify in the trophic network; and their deleterious effects impact the environment and the population health (Table 1). In humans, they enter the body mainly from indirect ingestion and affect various systems and organs, causing gastrointestinal, circulatory, neurological, and carcinogenic problems (BLUM, 2007). Industrial activities in different regions of Brazil, such as those developed by tanneries and mining companies, are responsible for the generation of sewers with high cadmium, chromium, lead, copper, and mercury concentrations (SILVA et al., 2014; HOENE et al., 2017).

The quality of the water used in agriculture is an important factor that may cause environmental impacts on the soil or irrigated plants; thus, the use of criteria for its management and control is essential. Table 2 presents reference values for irrigation of crops, including those produced in the semiarid region of Brazil, such as potato (Ipomoea batatas), cowpea (Vigna unguiculata), and common bean (Phaseolus vulgaris) (AYERS; WESTCOT, 1999; TRANI; TIVELLI; CARRIJO, 2011; EPA, 2012).

The main irrigation techniques adopted in the Brazilian semiarid for the reuse of water are drip, flood, furrows, and canals, which are characterized by reduction in water consumption, optimization of plant irrigation regimes, and increments in productivity (drip); and low cost and ease operation in the distribution of the solution (flooding, furrows, and canals), which present, as disadvantages, clogging of emitters, restriction to several crops that do not support periodic flooding, and the need for special care with the lining of the canals, respectively (COELHO et al., 2014).

Excess total dissolved solids in the irrigation water cause several problems, such as sodification, which damages soil structure and reduces water infiltration speed, affecting crop yield (BARROSO; WOLFF, 2011; MENEZES; MATOS, 2018). High concentrations of sodium and potassium can cause poor soil water infiltration and soil salinization, as well as chlorides, which are harmful to various crops at concentrations above $350 \mathrm{mg} \mathrm{L}^{-1}$ (SILVA et al., 2011). The electric conductivity of the solution allows a preliminary diagnosis of restriction and consequences on crop yield, according to the crops to be irrigated (TRANI; TIVELLI; CARRIJO, 2011; ROLIM et al., 2016). 
D. M. FERREIRA et al.

Table 2. Water quality for agricultural irrigation.

\begin{tabular}{|c|c|c|c|c|}
\hline \multirow{3}{*}{ Parameters } & \multicolumn{3}{|c|}{ Reference values ${ }^{1.2}$} & \multirow{3}{*}{ Reference values $^{3}$} \\
\hline & \multicolumn{3}{|c|}{ Water use restriction level } & \\
\hline & Low & Medium & High & \\
\hline \multirow{2}{*}{$\mathrm{EC}\left(\mu \mathrm{S} \mathrm{cm}^{-1}\right)$} & $<1000$ & $1000-2700$ & $>2700$ & \multirow{2}{*}{$500-1200$} \\
\hline & $<700$ & $700-3000$ & $>3000$ & \\
\hline \multirow{2}{*}{$\operatorname{TDS}\left(\mathrm{mg} \mathrm{L}^{-1}\right)$} & $<500$ & $500-1750$ & $>1750$ & \multirow{2}{*}{$480-832$} \\
\hline & $<450$ & $450-2000$ & $>2000$ & \\
\hline Carbonates $\mathrm{CO}_{3}{ }^{-2}\left(\mathrm{mg} \mathrm{L}^{-1}\right)$ & & $\leq 6$ & & - \\
\hline Bicarbonates $\mathrm{HCO}_{3}^{-}\left(\mathrm{mg} \mathrm{L}^{-1}\right)$ & $<90$ & $90-460$ & $>460$ & $60-120$ \\
\hline Sulfate $\mathrm{SO}_{4}^{++}\left(\mathrm{mg} \mathrm{L}^{-1}\right)$ & & $\leq 1000$ & & $100-250$ \\
\hline Calcium $\mathrm{Ca}^{++}\left(\mathrm{mg} \mathrm{L}^{-1}\right)$ & & $\leq 400$ & & $80-110$ \\
\hline Magnesium $\mathrm{Mg}^{++}\left(\mathrm{mg} \mathrm{L}^{-1}\right)$ & & $\leq 120$ & & $50-110$ \\
\hline Potassium K $\mathrm{K}^{+}\left(\mathrm{mg} \mathrm{L}^{-1}\right)$ & & - & & $5-100$ \\
\hline \multirow{2}{*}{ Sodium $\mathrm{Na}^{++}\left(\mathrm{mg} \mathrm{L}^{-1}\right)$} & $\leq 70$ & 70 & $>70$ & \multirow{2}{*}{$50-70$} \\
\hline & $<70$ & $>70$ & - & \\
\hline \multirow{2}{*}{ Chloride $\mathrm{Cl}^{-}\left(\mathrm{mg} \mathrm{L}^{-1}\right)$} & $<140$ & $140-530$ & $>530$ & \multirow{2}{*}{$70-100$} \\
\hline & $<70$ & $70-355$ & $>355$ & \\
\hline Total phosphorus $\mathrm{P}\left(\mathrm{mg} \mathrm{L}^{-1}\right)$ & & - & & 30 \\
\hline Total nitrogen $\mathrm{N}\left(\mathrm{mg} \mathrm{L}^{-1}\right)$ & & - & & $5-20$ \\
\hline $\mathrm{pH}$ & & $6.5-8.4$ & & $7-7.5$ \\
\hline Boron B $\left(\mathrm{mg} \mathrm{L}^{-1}\right)$ & $<0.7$ & $0.7-3.0$ & $>3.0$ & $0.5-1.0$ \\
\hline TC (MPN per $100 \mathrm{~mL})$ & & $10^{3}$ & & - \\
\hline Aluminum $\left(\mathrm{mg} \mathrm{L}^{-1}\right)$ & & 5.0 & & - \\
\hline $\operatorname{Arsenic}\left(\mathrm{mg} \mathrm{L}^{-1}\right)$ & & $0.05-0.10$ & & - \\
\hline Cadmium $\left(\mathrm{mg} \mathrm{L}^{-1}\right)$ & & 0.01 & & - \\
\hline Lead $\left(\mathrm{mg} \mathrm{L}^{-1}\right)$ & & 0.1 & & - \\
\hline Coper $\left(\mathrm{mg} \mathrm{L}^{-1}\right)$ & & $0.2-1.0$ & & - \\
\hline Chromium $\left(\mathrm{mg} \mathrm{L}^{-1}\right)$ & & $0.05-0.10$ & & - \\
\hline $\operatorname{Tin}\left(\mathrm{mg} \mathrm{L}^{-1}\right)$ & & 2.0 & & - \\
\hline Iron $\left(\mathrm{mg} \mathrm{L}^{-1}\right)$ & & $0.2-1.5$ & & - \\
\hline Manganese $\left(\mathrm{mg} \mathrm{L}^{-1}\right)$ & & $0.2-2.0$ & & - \\
\hline Mercury $\left(\mathrm{mg} \mathrm{L}^{-1}\right)$ & & 0.002 & & - \\
\hline Nickel $\left(\mathrm{mg} \mathrm{L}^{-1}\right)$ & & $0.2-0.5$ & & - \\
\hline Selenium $\left(\mathrm{mg} \mathrm{L}^{-1}\right)$ & & $0.01-0.02$ & & - \\
\hline Zinc $\left(\mathrm{mg} \mathrm{L}^{-1}\right)$ & & $1-5$ & & \\
\hline \multirow{2}{*}{ SAR } & $<5$ & $5-10$ & $>10$ & \multirow{2}{*}{$3-6$} \\
\hline & $<3$ & $3-9$ & $>9$ & \\
\hline
\end{tabular}

${ }^{1}$ Ayers; Westcot (1999); ${ }^{2}$ EPA (2012); ${ }^{3}$ Trani, Tivelli, Carrijo (2011). EC = electrical conductivity; TDS = total dissolved solids; $\mathrm{TC}=$ Thermotolerant Coliforms; SAR $=$ Sodium Adsorption Ratio.

Salts cause impacts on soils, resulting in low agricultural productivity and high production costs; increases in runoff and flooding events; and decreases in the aquifer recharge (PEDROTTI et al., 2015). Soil salinization compromises the development of plants because of the toxicity of some ions, reducing their growth and nutritional composition, and increasing the osmotic pressure, which keep the roots continually absorbing water (SILVA et al., 2018).

The salinization process is diagnosed from sodium, calcium, and magnesium ion concentrations, which determines the sodium adsorption ratio (SAR), an index that measures the degree to which sodium replaces calcium and magnesium adsorbed in the soil (AZEVEDO et al., 2017). The combination of this factor with electrical conductivity allows the classification of the irrigation water and its risks to crops and soil (RICHARDS, 1954). The Ayers and Westcot (1999) recommendations for agricultural use of residuary waters are international references to identify impacts caused by their use, which are adopted by the EPA (2012); they were appropriate to this research due to the high salt conditions in the water and sewage found in several municipalities of the Northeast region of Brazil (ARAÚJO NETO et al., 2015; SANTOS; PAIVA; SILVA, 2016).

Nutrients are essential to the development of agricultural crops. Despite no records of problems caused by excess phosphorus in irrigated crops were found, excess nitrogen slows maturity, reduces biomass production, and results in poor quality crops (SILVA et al., 2015; LIRA, 2015). Boron is an important nutrient, which is essential to plants in 
small quantities, but it can by toxic depending on its concentration and irrigated species; it can reach concentrations above $3 \mathrm{mg} \mathrm{L}^{-1}$ for irrigation of more resistant crops, such as onion (Allium cepa) and beet (Beta vulgaris). This element can bioaccumulate in crops due to irrigation and cause problems to the consumers' health (when overconsumed for long periods), affecting the nervous system (OLIVEIRA FILHO; DUTRA; CERUTI, 2012).

The concentrations proposed by Trani, Trivelli, Carrijo (2011) for aluminum, arsenic, cadmium, and chromium are compatible with those defined by EPA (2012). Cadmium is highly toxic to cowpea (Vigna unguiculata) at concentrations above $0.1 \mathrm{mg} \mathrm{L}^{-1}$ (POHLING, 2009). The concentration of lead for crop damage described in the literature is greater than $5 \mathrm{mg} \mathrm{L}$, which inhibits plant cell growth (EPA, 2012); it is 50 times higher than the maximum concentration described by US regulations (Table 2). Concentrations of copper and manganese of 0.1 to $1.0 \mathrm{mg} \mathrm{\textrm {L } ^ { - 1 }}$, cause problems in various plants, depending on the species sensitivity (POHLING, 2009).

The risk-benefit of the maximum values should be emphasized due to the problems caused by exposure of organisms to these elements, even at low concentrations, which can affect animals (organic changes) and humans (interfering with cognitive development). Carcinogens such as antimony, arsenic, cadmium, mercury, and selenium cause health problems depending on the form of exposure, rate, frequency, and absorption time (ROCHA; PEZZINI; POETA, 2017; RODRIGUES et al, 2017).

The expansion of water reuse in Brazil is directly related to general problems caused by the lack of planning and risk controls that do not consider impacts on the environment and public health (SCHAER-BARBOSA; SANTOS; MEDEIROS, 2014). Guiding documents, such as the Resolution No. 54/2005 (BRASIL, 2006), establish modalities, guidelines, and general criteria for water reuse; however, they do not describe requirements and limits for sewage quality regulation, causing insecurity to the population and compromising the progress of this practice (ROLIM et al., 2016). The Normative NBR 13969 (ABNT, 1997) presents recommendations for water reuse in agriculture (class 4), but they are limited to the concentrations of thermotolerant coliforms (TC) and dissolved oxygen, which are insufficient for a proper evaluation of the impacts involved.

Some regulations are focused on environmental education actions and control of some parameters at municipal and state levels. The Law 17,335 (SANTA CATARINA, 2017) instituted the Brazilian National Water Reuse Incentive Day (September 15), and the Law 7,424 (RIO DE JANEIRO, 2016) suggested water reuse by public administration agencies to increase employment in agriculture in general, but without indicating control criteria for water quality. The Municipal Law No. 4,603 of Caicó, RN (Brazilian semiarid region) (CAICÓ, 2013) describes criteria and quality standards for water reuse. The contents of thermotolerant coliforms (TC) and helminths in waters used for agriculture in Brazil are based on the WHO (2006) recommendations; and electrical conductivity, $\mathrm{pH}$, and SAR are based on the EPA (2012) and Ayers and Westcot (1999).

Other secondary legislations interesting for this discussion compare these internationally established limits, such as the Brazilian Environmental Council Resolutions - CONAMA No. 357, 396 and 430 (BRASIL, 2005, 2011a, 2011b) and the COEMA Resolution No. 02 (CEARÁ, 2017) (Table 3). These resolutions describe, respectively, the classification of water bodies and guidelines for their use in framing activities; classification and environmental guidelines for use of groundwater in framing activities; effluent discharge conditions and standards; and standards for water reuse in agriculture and applications on soil.

The resolution for groundwater use deserves some considerations. The predicted values are, in some cases, above those of other resolutions, but do not imply risks to crops and the environment, since they are in accordance with international guidelines adopted for water reuse (EPA, 2012), such as those for metals and boron. Risks to crops for these elements are found at concentrations higher than 1.0 mg L $\mathrm{L}^{-1}$ (POHLING, 2009; OLIVEIRA FILHO; DUTRA; CERUTI, 2012). Lead concentration is also above those of other references, but it does not imply risks, since the literature predicts damages to crops at concentrations above $5.0 \mathrm{mg} \mathrm{L}^{-1}$ (EPA, 2012). The limits for copper, manganese, nickel, and zinc vary according to the irrigated crop, and are adopted due to their toxic effects (POHLING, 2009).

Limits of these parameters for application of sewage on soils are established by the COEMA Resolution No. 02 (CEARÁ, 2017), considering the water reuse in agriculture. Electrical conductivity and SAR are not found in the other legislations (Table 3), but they are indicative of risks of soil salinity and sodicity, respectively. The first is classified as low risk, but the second has upper limits for toxicity, as defined by Ayers and Westcot (1999), and EPA (2012). The internationally established BOD and $\mathrm{pH}$ values are similar to those described in the Brazilian legislation for sewage disposal, as well as for metals, except for chromium, manganese, and selenium. The wide variety of irrigated crops, their specific limit concentrations, and the main area of application of the resolution (semiarid) corroborate the described levels. 
D. M. FERREIRA et al.

Table 3. Maximum limits of different parameters for irrigation water and sewage discharge, based on Brazilian resolutions.

\begin{tabular}{|c|c|c|c|c|}
\hline \multirow{3}{*}{ Parameters } & \multicolumn{4}{|c|}{ Maximum values } \\
\hline & \multicolumn{4}{|c|}{ Resolutions (water type) } \\
\hline & $\begin{array}{l}357 / 2005^{1} \\
\text { (Surface) } \\
\end{array}$ & $\begin{array}{c}396 / 2008 \\
\text { (Groundwater) } \\
\end{array}$ & $\begin{array}{c}430 / 2011 \\
\text { (Effluents) }\end{array}$ & $\begin{array}{r}02 / 2017 \\
\text { COEMA } \\
\end{array}$ \\
\hline $\mathrm{EC}\left(\mu \mathrm{S} \mathrm{cm}^{-1}\right)$ & NA & $\mathrm{NA}$ & NA & 1000 \\
\hline TC (MPN per $100 \mathrm{~mL})$ & $4 \times 10^{3}$ & NA & NA & $5 \times 10^{3}$ \\
\hline $\mathrm{BOD}\left(\mathrm{mg} \mathrm{O}_{2} \mathrm{~L}^{-1}\right)$ & 10.0 & NA & 120 & 120 \\
\hline Total phosphorus $\left(\mathrm{mg} \mathrm{L}^{-1}\right)$ & 0.15 & NA & NA & NA \\
\hline Total nitrogen $\left(\mathrm{mg} \mathrm{L}^{-1}\right)$ & 24 & NA & 20 & NA \\
\hline $\mathrm{pH}$ & $6-9$ & NA & $5-9$ & $5-9$ \\
\hline Boron $\left(\mathrm{mg} \mathrm{L}^{-1}\right)$ & 0.75 & 0.5 & 5.0 & 5 \\
\hline Aluminum $\left(\mathrm{mg} \mathrm{L}^{-1}\right)$ & 0.2 & 5 & NA & 10.0 \\
\hline $\operatorname{Arsenic}\left(\mathrm{mg} \mathrm{L}^{-1}\right)$ & 0.033 & NA & 0.5 & 0.5 \\
\hline Cadmium $\left(\mathrm{mg} \mathrm{L}^{-1}\right)$ & 0.01 & 0.01 & 0.2 & 0.2 \\
\hline Lead $\left(\mathrm{mg} \mathrm{L}^{-1}\right)$ & 0.033 & 5 & 0.5 & 0.5 \\
\hline Coper $\left(\mathrm{mg} \mathrm{L}^{-1}\right)$ & 0.013 & 0.2 & 1.0 & 1 \\
\hline Chromium $\left(\mathrm{mg} \mathrm{L}^{-1}\right)$ & 0.05 & 0.1 & 1.1 & 0.1 \\
\hline $\operatorname{Tin}\left(\mathrm{mg} \mathrm{L}^{-1}\right)$ & NA & NA & 4 & 4 \\
\hline $\operatorname{Iron}\left(\mathrm{mg} \mathrm{L}^{-1}\right)$ & 5 & 5 & 15 & 15 \\
\hline Manganese $\left(\mathrm{mg} \mathrm{L}^{-1}\right)$ & 0.5 & 0.2 & 10 & 1 \\
\hline Mercury $\left(\mathrm{mg} \mathrm{L}^{-1}\right)$ & 0.002 & 0.002 & 0.01 & 0.01 \\
\hline $\operatorname{Nickel}\left(\mathrm{mg} \mathrm{L}^{-1}\right)$ & 0.025 & 0.2 & 2 & 2 \\
\hline Silver $\left(\mathrm{mg} \mathrm{L}^{-1}\right)$ & 0.05 & NA & 0.1 & 0.1 \\
\hline Selenium $\left(\mathrm{mg} \mathrm{L}^{-1}\right)$ & 0.05 & 0.02 & 0.3 & 0.05 \\
\hline $\operatorname{Zinc}\left(\mathrm{mg} \mathrm{L}^{-1}\right)$ & 5 & 2 & 5 & 5 \\
\hline SAR & NA & NA & NA & 10 \\
\hline
\end{tabular}

Brasil (2005; 2011a; 2011b); CEARÁ (2017). ${ }^{1}$ Classe 3.b = Irrigation of tree, cereal, and fodder crops. COEMA = Environmental Council of the State of Ceará (Brazil); EC = Electrical Conductivity; TC $=$ Thermotolerant Coliforms; MPN $=$ most probable number; BOD = Biochemical Oxygen Demand; SAR = Sodium Adsorption Ratio; NA = not available.

The compilation of reference values for water reuse in agriculture in the present study (Table 4) includes all variables in laws and documents associated with this issue, since it is the first compilation of these variables in Brazil.

Based on national scientific research, the limits established for the Northeast region of Brazil for sewage treatment systems are representative of the national conditions regarding the type of treatments employed and their operational efficiency levels. The minimum concentrations for different stabilization pond treatment systems are also similar to those usually found in the literature; and the maximum concentrations found in the laws were applicable to the Brazilian conditions.

Facultative stabilization pond treatment systems intend to remove organic matter. However, in many seasons, the final concentration expressed as BOD is above the recommended concentrations described for water reuse (international standards) and disposal into water bodies (BRASIL, 2011b). Researches in the state of Rio Grande do Norte confirm this information through monitoring of sewage treatment systems, mostly in the semiarid region, showing concentrations in treated sewages ranging from 90 to $190 \mathrm{mg} \mathrm{L}^{-1}$ (ARAÚJO, 2017).

The proposed range is compatible with the expected final concentrations found in the literature for these systems. Evaluations of the efficiency of sewage treatment systems in several Brazilian states confirm this range, with average values of 25 to 150 mg L ${ }^{-1}$ (GONÇALVES, et al., 2015; QUEIROZ; QUEIROZ; ARAGÃO, 2015). Regarding the agricultural application, effluents with concentrations above $65 \mathrm{mg} \mathrm{L}^{-1}$ were applied as fertigation to crops in the semiarid region and did not interfere with their growth (RIBEIRO et al., 2012; SALGADO et al., 2018).

Acid water with $\mathrm{pH}$ below 6 directly affects irrigated crops and soil, with increasing effect in medium and long terms (SILVA et al., 2018). The $\mathrm{pH}$ values commonly found for domestic sewage are neutral to slightly alkaline, offering no risks, as evidenced by Queiroz, Queiroz, Aragão (2015); Silva et al. (2015), and Rolim et al. (2016), who found $\mathrm{pHs}$ of 6.50 to 8.40 . 
D. M. FERREIRA et al.

Table 4. Compilation of parameter limits for wastewater obtained from domestic sewage for agricultural purposes.

\begin{tabular}{|c|c|c|c|}
\hline Classification & Parameters & Limits & $\begin{array}{l}\text { Reference } \\
\text { Document }\end{array}$ \\
\hline & $\mathrm{BOD}\left(\mathrm{mg} \mathrm{O}_{2} \mathrm{~L}^{-1}\right)$ & $60-120$ & $2 ; 3 ; 6 ; 8$ \\
\hline Organic Matter & Total phosphorus $\left(\mathrm{mg} \mathrm{L}^{-1}\right)$ & $4-30$ & $2 ; 7 ; 8$ \\
\hline Nutrients & Total nitrogen $\left(\mathrm{mg} \mathrm{L}^{-1}\right)$ & $20-70$ & $2 ; 3 ; 6 ; 7 ; 8$ \\
\hline \multirow{2}{*}{$\mathrm{pH}$} & $\mathrm{pH}$ & $6-9$ & $1 ; 2 ; 3 ; 7 ; 8$ \\
\hline & Boron $\left(\mathrm{mg} \mathrm{L}^{-1}\right)$ & $0.5-3.0$ & $1 ; 3 ; 5 ; 7 ; 8$ \\
\hline \multirow{10}{*}{ Salts } & Electrical conductivity $\left(\mu \mathrm{S} \mathrm{cm}^{-1}\right)$ & $500-2700$ & $1 ; 7 ; 8$ \\
\hline & Total dissolved solids $\left(\mathrm{mg} \mathrm{L}^{-1}\right)$ & $450-2000$ & $1 ; 8$ \\
\hline & Suspended solids $\left(\mathrm{mg} \mathrm{L}^{-1}\right)$ & $10-150$ & 8 \\
\hline & Carbonates $\mathrm{CO}_{3}^{-2}\left(\mathrm{mg} \mathrm{L}^{-1}\right)$ & 6 & 1 \\
\hline & Bicarbonates $\mathrm{HCO}_{3}^{-}\left(\mathrm{mg} \mathrm{L}^{-1}\right)$ & $60-460$ & $1 ; 7$ \\
\hline & Sulfate $\mathrm{SO}_{4}^{++}\left(\mathrm{mg} \mathrm{L}^{-1}\right)$ & $100-1000$ & $1 ; 7$ \\
\hline & Calcium $\mathrm{Ca}^{++}\left(\mathrm{mg} \mathrm{L}^{-1}\right)$ & $80-400$ & $1 ; 7$ \\
\hline & Magnesium $\mathrm{Mg}^{++}\left(\mathrm{mg} \mathrm{L}^{-1}\right)$ & $50-120$ & $1 ; 7$ \\
\hline & Sodium $\mathrm{Na}^{+}\left(\mathrm{mg} \mathrm{L}^{-1}\right)$ & $50-70$ & $1 ; 7$ \\
\hline & Chloride $\mathrm{Cl}^{-}\left(\mathrm{mg} \mathrm{L}^{-1}\right)$ & $70-530$ & $1 ; 7 ; 8$ \\
\hline \multirow{13}{*}{ Metals } & Aluminum $\left(\mathrm{mg} \mathrm{L}^{-1}\right)$ & 5.0 & $5 ; 7 ; 8$ \\
\hline & Arsenic $\left(\mathrm{mg} \mathrm{L}^{-1}\right)$ & $0.05-0.10$ & $7 ; 8$ \\
\hline & Cadmium $\left(\mathrm{mg} \mathrm{L}^{-1}\right)$ & 0.01 & $3 ; 5 ; 7 ; 8$ \\
\hline & Lead $\left(\mathrm{mg} \mathrm{L}^{-1}\right)$ & $0.1-5.0$ & $6 ; 7 ; 8$ \\
\hline & Coper $\left(\mathrm{mg} \mathrm{L}^{-1}\right)$ & $0.2-1.0$ & $5 ; 7 ; 8$ \\
\hline & Chromium $\left(\mathrm{mg} \mathrm{L}^{-1}\right)$ & $0.05-0.10$ & $3 ; 5 ; 7 ; 8$ \\
\hline & $\operatorname{Tin}\left(\mathrm{mg} \mathrm{L}^{-1}\right)$ & 2.0 & 7 \\
\hline & $\operatorname{Iron}\left(\mathrm{mg} \mathrm{L}^{-1}\right)$ & $0.2-5.0$ & $3 ; 5 ; 7 ; 8$ \\
\hline & Manganese $\left(\mathrm{mg} \mathrm{L}^{-1}\right)$ & $0.2-2.0$ & 7 \\
\hline & Mercury $\left(\mathrm{mg} \mathrm{L}^{-1}\right)$ & 0.002 & $5 ; 7$ \\
\hline & Nickel $\left(\mathrm{mg} \mathrm{L}^{-1}\right)$ & $0.2-0.5$ & $5 ; 7 ; 8$ \\
\hline & Selenium $\left(\mathrm{mg} \mathrm{L}^{-1}\right)$ & $0.02-0.05$ & $3 ; 5 ; 7$ \\
\hline & $\operatorname{Zinc}\left(\mathrm{mg} \mathrm{L}^{-1}\right)$ & $2-5$ & $3 ; 5 ; 7 ; 8$ \\
\hline \multirow{3}{*}{ Pathogens } & Thermotolerant coliforms (MPN per $100 \mathrm{~mL}$ ) & $10^{3}-10^{5}$ & 4 \\
\hline & Helminths (Viable eggs L-1) & $\leq 1$ & 4 \\
\hline & SAR & $3-10$ & $1 ; 7 ; 8$ \\
\hline
\end{tabular}

Regarding the nutrients, the phosphorus contents found in sewage treatment systems for subsequent agricultural use were 3.00 to $12.80 \mathrm{mg} \mathrm{L}^{-1}$; these contents are relevant for plant growth (FREITAS et al., 2012; QUEIROZ; QUEIROZ; ARAGÃO, 2015). Nitrogen were found in concentrations of 17 to $35 \mathrm{mg} \mathrm{L}^{-1}$, which is suitable for most crops grown in the study environment (RIBEIRO et al., 2012; ANDRADE FILHO et al., 2013). Higher concentrations were found in sewage treatment systems in the Brazilian Southeast region (Araras, SP; Alegre, ES; and Botucatu, SP), ranging from 45 to $77 \mathrm{mg} \mathrm{L}^{-1}$, (GARCIA et al., 2012; PINTO et al., 2013; SOUZA et al., 2015).

Several Brazilian municipalities have high salt concentrations in the sewage, due to the use of waters from wells, which are, in some cases, brackish waters. High sodium content combined with low calcium and magnesium contents generates high SAR levels, which compromises the development of several crops, depending on their sensitivity (PIVELLI et al., 2009). This was found in studies in the Northeast region and in São Paulo municipalities, presenting SAR of 4 to 7 , denoting a moderate use restriction level (CUBA et al., 2015; ROLIM et al., 2016; MARQUES et al., 2018).

Regarding pathogens, the proposed concentrations are in accordance with the international limits (WHO, 2006) and are ratified by researches in Brazil.

Helminths were evaluated in Cravolândia, BA (OLIVEIRA et al., 2013) and in Petrolândia, PE (SOUZA FILHO et al., 2017), showing zero viable eggs per liter; however, in sewage treatment systems in Piracicaba and Piracamirim, SP, Santos et al. (2012) found approximately 1 and 4 viable eggs $L^{-1}$, respectively.

Rebouças et al. (2010) and Cuba et al. (2015) evaluated thermotolerant coliforms in sewage waters used for irrigation in cowpea (Vigna unguiculata) and lettuce (Lactuca sativa), in São Carlos, SP, and in Mossoró, RN, Brazil, and found values of $1.5 \times 10^{2}$ and $2.2 \times 10^{4} \mathrm{MPN}$ per $100 \mathrm{~mL}$, respectively. The crops presented good yield, the treatment did not compromise their development, and no coliforms 
were found in the products, denoting the efficiency and safety of the water reuse.

Metal monitoring is important for water safety, mainly when the sewage is not subjected to proper treatment, which is commonly found in Brazil. Several studies present non-quantifiable values of metals. Andrade Filho et al. (2013), Oliveira et al. (2014), Queiroz, Queiroz and Aragão (2015), and Salgado et al. (2018) evaluated copper, iron, manganese, and zinc contents in sewages used for irrigation in the Brazilian semiarid region and found 0.02 to $0.45 \mathrm{mg} \mathrm{L}^{-1}(\mathrm{Cu}), 0.18$ to $2.20 \mathrm{mg} \mathrm{L}^{-1}$ (Fe), 0.07 to $0.15 \mathrm{mg} \mathrm{L}^{-1}(\mathrm{Mn})$, and 0.05 to $1.25 \mathrm{mg}$ $\mathrm{L}^{-1}(\mathrm{Zn})$, with no effect on the development of the crops.

Although there is no history of contamination by metals such as lead, selenium, and mercury in sewage treatment systems in Brazil, they are present in products used in various activities. Mercury, for example, is likely to be found because of its use in dental office amalgams, which are disposed directly in the sewage collection system (JESUS; MARINHA; MOREIRA, 2010; SANTOS; DIAS; SANTOS, 2016). Other practices can add this element to domestic sewage on a national scale, such as the consumption of fish from contaminated rivers and gold mining.

\section{CONCLUSIONS}

Monitoring and investigating the quality conditions of sewage waters in Brazil are important for safety and development of their use, since they have been used usually informally, especially in the Northeast semiarid region of Brazil. This means that there is no quality control of the reused water, nor studies on risks for soil and irrigated crops and impacts on human health.

The purpose of this research is mainly to assist in the composition of guiding documents for safety in water reuse in agriculture in Brazil due to the need for adopting effective control tools for the full development of this practice.

\section{REFERENCES}

AGÊNCIA NACIONAL DE ÁGUAS - ANA. Atlas esgotos: despoluição de bacias hidrográficas. Agência Nacional de Águas, Secretaria Nacional de Saneamento Ambiental. Brasília: ANA, 2017a. 88 p.

AGÊNCIA NACIONAL DE ÁGUAS - ANA. Conjuntura dos recursos hídricos no Brasil 2017: relatório pleno. Agência Nacional de Águas. Brasília: ANA, 2017b. 169 p.
ANDRADE FILHO, J. et al. Atributos químicos de solo fertirrigado com água residuária no semiárido brasileiro. IRRIGA, v. 18, n. 4, p. 661-674, 2013.

ARAÚJO, A. L. C. Avaliação operacional e da eficiência de sistemas de lagoas de estabilização no Rio Grande do Norte. Caderno de pesquisa em Engenharia de Saúde Pública. Ministério da Saúde, Fundação Nacional de Saúde. Brasília: Funasa, v. 1, n. 8, p. 39-71, 2017.

ARAÚJO, G. M. et al. Avaliação experimental e modelagem matemática de filtros anaeróbios como alternativa de baixo custo para remoção de algas de efluente de lagoas de estabilização. Engenharia Sanitária e Ambiental, v. 21, n. 4, p. 687-696, out/ dez. 2016

ARAÚJO NETO, J. R. et al. Dinâmica da qualidade das águas superficiais para Irrigação em reservatórios do estado do Ceará, Brasil. Conexão Ciência e Tecnologia, v. 9, n. 1, p. 51-60, 2015.

ASSOCIAÇÃO BRASILEIRA DE NORMAS TÉCNICAS - ABNT. NBR 13969: Tanques sépticos - Unidades de tratamento complementar disposição final dos efluentes líquidos - Projeto, construção e operação. Rio de Janeiro, 1997.

AYERS, R. S.; WESTCOT, D. W. A qualidade da água na agricultura. 1. rev. Campina Grande, $\mathrm{PB}$ : UFPB, 1999. 218 p.

AZEVEDO, P. R. L. et al. Efeito dos sais e da qualidade da água no solo e na planta. Agroecologia no Semiárido, v. 1, n. 1, p. 1-12, 2017.

BARROSO, L. B.; WOLFF, D. B. Reúso de esgoto sanitário na irrigação de culturas agrícolas. Engenharia Ambiental Pesquisa e Tecnologia, v. 8 , n. 3, p. 225-236, 2011.

BECERRA-CASTRO, C. et al. Wastewater reuse in irrigation: A microbiological perspective on implications in soil fertility and human and environmental health. Environment International, v. 75, s/n., p. 117-135, 2015.

BEZERRA, M. B.; BEZERRA, A. P. P. S. A crise hídrica como reflexo da seca: o Nordeste Setentrional em alerta. Revista de Geociências do Nordeste, v. 2, s/n., p. 623-632, 2016.

BLUM, J. R. C. Critérios e padrões de qualidade da água. In: MANCUSO, P. C. S.; SANTOS, H. F. (Eds.). Reuso de água. Barueri, SP: Manole, 2007. 1. reimpressão, cap. 5 , p. 125-174. 
BRASIL. Conselho Nacional de Recursos Hídricos. Resolução n. 54 - 28 nov. 2005. Estabelece modalidades, diretrizes para a prática do reuso direto não potável de água e dá outras providências. Diário Oficial da União, Brasília, 9 mar. 2006.

BRASIL. Ministério do Meio Ambiente. Resolução n. 396 - 03 abr. 2008. Dispõe sobre a classificação e diretrizes ambientais para o enquadramento das águas subterrâneas e dá outras providências. Diário Oficial da União, Brasília, 16 maio 2011a.

BRASIL. Ministério do Meio Ambiente. Resolução n. 430 - 13 maio 2011. Dispõe sobre as condições e padrões de lançamento de efluentes, complementa e altera a Resolução n. 357, de 17 de março de 2005, do Conselho Nacional do Meio Ambiente CONAMA. Diário Oficial da União, Brasília, 16 maio $2011 \mathrm{~b}$.

BRASIL. Secretaria Nacional do Meio Ambiente. Resolução n. 357 - 17 mar. 2005. Dispõe sobre a classificação dos corpos de água e diretrizes ambientais para o seu enquadramento, bem como estabelece as condições e padrões de lançamento de efluentes, e dá outras providências. Diário Oficial da União, Brasília, 18 mar. 2005.

CAICÓ. Lei $\mathrm{n}^{0}$ 4.603, de 26 de agosto de 2013. Recomenda critérios e padrões de qualidade para água de reuso a ser utilizada nas seguintes atividades: produção agrícola, fins urbanos, piscicultura e dá outras providências. Disponível em: $<$ https://caico.rn.gov.br/leis.php?id=2471 $>$. Acesso em: 23 ago. 2019

CANTELlE, T. D.; LIMA, E. C.; BORGES, L. A.C. Panorama dos recursos hídricos no mundo e no Brasil. Revista em Agronegócio e Meio Ambiental, v. 11, n. 4, p. $1259-1282,2018$

CEARÁ. Resolução COEMA $\mathbf{N}^{\circ} 02$, de 02 de fevereiro de 2017. Dispõe sobre padrões e condições para lançamento de efluentes líquidos gerados por fontes poluidoras. Disponível em: < $\underline{\mathrm{https}}$ :// www.legisweb.com.br/legislacao/? $\mathrm{id}=337973 />$. Acesso em: 23 ago. 2019.

CIRILO, J. A. Crise hídrica: desafios e superação. Revista USP, v. 1, n. 106, p. 45-58, 2015.

COELHO, E. F. et al. Sistema e manejo de irrigação de baixo custo para a agricultura familiar. Cruz das almas, BA: Embrapa Mandioca e Fruticultura, 2014. 45 p.

CUBA, R. S. et al. Potencial de efluente de esgoto doméstico tratado como fonte de água e nutrientes no cultivo hidropônico de alface. Ambiente \& Água, v.
10, n. 3, p. $574-586,2015$.

EPA - ENVIRONMENTAL PROTECTION AGENCY OF UNITED STATES (USEPA). Guidelines for Water Reuse. Washington: USEPA, 2012.

FREITAS, C. A. S. et al. Crescimento da cultura do girassol irrigado com diferentes tipos de água e adubação nitrogenada. Revista Brasileira de Engenharia Agrícola e Ambiental, v. 16, n. 10, p. 1031-1039, 2012.

GARCIA, G. O. et al. Propriedades químicas de um solo cultivado com duas forrageiras fertirrigadas com esgoto doméstico tratado. Revista Brasileira de Ciências Agrárias, v. 7, sup., p. 737-742, 2012.

GONÇALVES, C. A. M. et al. Avaliação da eficiência de duas modalidades de tratamento de esgoto em escala real e de grande porte. Revista NBC, v. 5, n. 10, p. 6-15, 2015.

HESPANHOL, I. A Inexorabilidade do reúso potável direto. Revista DAE, v. 63, n. 198, p. 63-82, 2015 a.

HESPANHOL, I. Reúso potável direto e o desafio dos poluentes emergentes. Revista USP, v. 1, n. 106, p. 79-94, 2015b.

HOENE, L. et al. Aplicação da vermicompostagem no resíduo tratado de indústria de curtume para cultivo de rúculas. Destaques Acadêmicos, v. 9, n. 4, p. 104-120, 2017.

JACOBI, P. R.; EMPINOTTI, V. L.; SCHMIDT, L. Escassez hídrica e direitos humanos. Ambiente \& Sociedade, v. 29, n. 1, p. 1-5, 2016.

JESUS, L. F.; MARINHA, M. S.; MOREIRA, F. R. Amálgama dentário: fonte de contaminação por mercúrio para a Odontologia e para o meio ambiente. Cadernos Saúde Coletiva, v. 18, n. 4, p. 509-515, 2010.

KUBLER; H; FORTIN, A; MOLLETA, L. Reúso de água nas crises hídricas e oportunidades no Brasil. 1. ed. Rio de Janeiro: ABES, 2015. 43 p.

LIRA, R. M. et al. A utilização de águas de qualidade inferior na agricultura irrigada. Revista Geama - Environmental Sciences, v. 1, n. 3, p. 341 $-362,2015$.

LUCENA, C. Y. S. et al. O reuso de águas residuais como meio de convivência com a seca no semiárido do Nordeste brasileiro. REGNE, v. 4, sup., p. 1-17, 2018 .

MARQUES, M. V. et al. A. Sodicidade e salinidade 
de solo submetido à fertirrigação com esgoto bruto aplicado em sulcos fechados. Revista Engenharia na Agricultura, v. 26, n. 5, p. 464-472, 2018.

MELO JÚNIOR, A. S. et al. Avaliação da Demanda Bioquímica de Oxigênio (DBO) em uma lagoa facultativa. INOVAE, v. 6, n. 1, p. 300-319, 2018.

MENDONÇA, L. C.; MENDONÇA, S. R. Características dos esgotos sanitários. In: MENDONÇA, S. R.; MENDONÇA, L. C. (Eds.). Sistemas sustentáveis de esgotos. São Paulo: Blucher, 2017, 2 ed., cap. 1, p. 19-59.

MENDONÇA, L. C. A importância do reúso de efluentes de esgotos domésticos tratados na agricultura. In: MENDONÇA, S. R.; MENDONÇA, L. C. (Eds.). Sistemas sustentáveis de esgotos. São Paulo: Blucher, 2017, 2 ed., cap. 9, p. 291-315.

MENEZES, A. N.; MATOS, A. T. condutividade elétrica do solo em função da dose de aplicação de água residuária em áreas de fertirrigação. Revista Engenharia na Agricultura, v. 26, n. 4, p. 383-389, 2018.

OLIVEIRA, A. F. M. et al. Teores de metais pesados em cambissolo irrigado com água residuária doméstica e água de poço. Ambiente \& Água, v. 9, n. 2 , p. $302-312,2014$

OLIVEIRA FILHO, P. C. O.; DUTRA; A. M.; CERUTI, C. Qualidade das Águas Superficiais e o Uso da Terra: Estudo de Caso Pontual em Bacia Hidrográfica do Oeste do Paraná. Floresta e Ambiente, v. 19, n. 1, p. 32-43, 2012.

OLIVEIRA, P. C. P. et al. Produção de moranga irrigada com esgoto doméstico tratado. Revista Brasileira de Engenharia Agrícola e Ambiental, v. 17 , n. 8, p. 861-867, 2013.

PEDROTTI, A. et al. Causas e consequências do processo de salinização dos solos. Revista Eletrônica em Gestão, Educação e Tecnologia Ambiental, v. 19, n. 2, p. 1308-1324, 2015.

PINTO, M. C. K. et al. Contaminação das águas subterrâneas por nitrogênio devido à irrigação com efluente do tratamento de esgoto. Irriga, v. 18, n. 2, p. 270-281, 2013.

PIVELLI, R. P. et al. Remoção de Nutrientes em Sistemas Naturais. In: MOTA, F. S. B.; VON SPERLING, M. (Eds.). Nutrientes de esgoto sanitário: utilização e remoção. Rio de Janeiro: ABES, 2009, v. 2, cap. 9, p. 293-340.

POHLING, R. Reações químicas na análise de água. 1. ed. Fortaleza: Arte visual Gráfica e Editora
LTDA, 2009. 334 p.

QUEIROZ, A. A.; QUEIROZ, S. O. P.; ARAGÃO, C. A. Reúso de efluentes domésticos na irrigação por gotejamento do tomateiro. Pesquisa Agropecuária Pernambucana, v. 20, n. 1, p. 36-42, 2015.

REBOUÇAS, L. et al. Crescimento do feijão-caupi irrigado com água residuária de esgoto doméstico tratado. Revista Caatinga, v. 23, n. 1, p. 97-102, 2010 .

RIBEIRO, M. C. F. et al. Crescimento e produtividade da mamoneira irrigada com diferentes diluições de esgoto doméstico tratado. Revista Brasileira de Engenharia Agrícola e Ambiental, v. 16, n. 6, p. 639-646, 2012.

RICHARDS, L. A. Diagnosis and improvement of saline and alkali soils. Washington: United States Salinity Laboratory, 1954. 160 p.

RIO DE JANEIRO. Lei $\mathbf{n}^{\circ} \mathbf{7 . 4 2 4}$, de 24 de agosto de 2016. Utilização de água de reúso pelos órgãos integrantes da administração pública estadual direta, das autarquias, das fundações instituídas ou mantidas pelo poder público, das empresas em cujo capital do estado do rio de janeiro tenha participação, bem como pelas demais entidades por ele controladas direta ou indiretamente. Disponível em: $<$ https://gov -rj.jusbrasil.com.br/legislacao/379240994/lei-742416-rio-de-janeiro-rj>. Acesso em: 23 ago. 2019

ROCHA, R.; PEZZINI, F. M.; POETA, J. Fontes de contaminação pelo chumbo e seus efeitos tóxicos na saúde ocupacional. Ciência em Movimento, v. 19 n. 39, p. $23-32,2017$.

RODRIGUES, T. F. et al. A ação dos metais pesados originários de rejeitos de mineração sobre a saúde humana e seu impacto ao meio ambiente. Semioses, v. 11, n. 2, p. 82-87, 2017.

ROLIM, H. O. R. et al. Qualidade dos efluentes de sistemas de tratamento biológico UASB e UCT para reúso agrícola. Revista em Agronegócio e Meio Ambiente, v. 9, n. 2, p. 393-414, 2016.

SALGADO, V. C. et al. Cultivo de melancia no semiárido irrigado com diferentes lâminas de esgoto doméstico tratado. Engenharia Sanitária e Ambiental, v. 23, n. 4, p. 727-738, 2018.

SANTA CATARINA. Lei $\mathbf{n}^{\circ} \mathbf{1 7 . 3 3 5}$, de 30 de novembro de 2017. Consolida as Leis que dispõem sobre a instituição de datas e festividades alusivas no âmbito do Estado de Santa Catarina. Disponível em: $<$ http://leis.alesc.sc.gov.br/ html/2017/17335 2017 lei.html>. Acesso em: 23 ago. 2019 
SANTOS, J. G. Análise parasitológica em efluentes de Estações de Tratamento de Águas residuárias. Revista de Patologia Tropical, v. 41, n. 3, p. 319336, 2012.

SANTOS, D. T.; DIAS, K. R. H. C; SANTOS, M. P. A. Amálgama dental e seu papel na Odontologia atual. Revista Brasileira de Odontologia, v. 73, n. 1, p. 64-68, 2016.

SANTOS, S. M.; PAIVA, A. L. R.; SILVA, V. F. Qualidade da água em barragem subterrânea no semiárido. Revista Brasileira de Agricultura Irrigada, v. 10, n. 3, p. 62-66, 2016.

SCHAER-BARBOSA, M.; SANTOS, M. E. P; MEDEIROS, Y. D. P. Viabilidade do reúso de água como elemento mitigador dos efeitos da seca no semiárido da Bahia. Ambiente \& Sociedade, v. 17, n. 2, p. 17-32, 2014.

SILVA, J. C. J. et al. Determinação de metais pesados em amostras de sedimentos superficiais da bacia do rio São Francisco por espectrometria de massas com fonte de plasma acoplada indutivamente após decomposição ácida assistida por radiação micro-ondas. Eclética Química, v. 39, n. 1, p. 22-34, 2014.

SILVA, J. R. I. et al. Estresse salino como desafio para produção de plantas forrageiras. Pesquisa Aplicada \& Agrotecnologia, v. 11, n. 3, p. 127-139, 2018.

SILVA, L. L. et al. Produção da pimenta tekila bode vermelha irrigada com efluente tratado sob diferentes concentrações. Revista AGROTEC, v. 36, n. 1, p. 9 $-15,2015$.

SILVA, M. B. R. et al. Crescimento e produção do pinhão-manso irrigado com água residuária sob condições de estresse hídrico. Revista Brasileira de Engenharia Agrícola e Ambiental, v. 15, n. 6, p. 621-629, 2011.

SOUZA FILHO, E. J. et al. Níveis de adubação no cultivo de melancia irrigado com esgoto. Revista DAE, v. 65, n. 207, p. 94-106, 2017.

SOUZA, C. F. et al. Eficiência de estação de tratamento de esgoto doméstico visando reuso agrícola. Ambiente \& Água, v. 10, n. 3, p. 587-597, 2015.

TRANI, P. E; TIVELLI, S. W.; CARRIJO, O. A. Fertirrigação em hortaliças. 2. ed. revista e atualizada Campinas, SP: Instituto Agronômico,
$2011.51 \mathrm{p}$.

TUNDISI, J. G.; TUNDISI, T. M. As múltiplas dimensões da crise hídrica. Revista USP, v. 1, n 106, p. 21-30, 2015.

UCKER, F. E.; et al. Elementos interferentes na qualidade da água para irrigação. Revista Eletrônica em Gestão, Educação e Tecnologia Ambiental, v. 10, n. 10, p. 2102-2111, 2013.

VERIATO, M. K. L. et al. Água: Escassez, crise e perspectivas para 2050. Revista Verde, v. 10, n. 5, p. 17-22, 2015.

VON SPERLING, M. Lagoas de estabilização. 2. ed. Belo Horizonte: UFMG/DESA, 2002. 196 p.

WORLD HEALTH ORGANIZATION - WHO. Guidelines for the safe use of wastewater, excreta and greywater. Genebra: WHO, v. 2, 2006. 222 p. 